\author{
V.M. Kaminskii, Z.D. Kovalyuk, V.I. Ivanov, I.G. Tkachyuk, V.V. Netyaga
}

\title{
Electrical Properties of Cd Doped InSe Crystals
}

\author{
I.M. Frantsevich Institute for Problems of Materials Science of the National Academy of Sciences of Ukraine, Chernivtsi \\ Department, Iryna Vilde str., 5, 58001 Chernivtsi, Ukraine, e-mail chimsp@ukrpost.ua
}

\begin{abstract}
The measurements of electrical conductivity along (alternating electric field) and across (direct electric field) the crystallographic $\boldsymbol{C}$ axis of $\mathrm{Cd}$-doped indium selenide single crystals are carried out. The parameters of the hopping conductivity of $\mathrm{InSe}<\mathrm{Cd}>$ are calculated.
\end{abstract}

Keywords: layered crystal, indium selenide, conductivity.

Article acted received 17.04.2018; accepted for publication 15.06.2018.

\section{Introduction}

InSe layered semiconductor crystals can be used as an effective material for various heterostructures [1-3]. The advantage of heterostructures based on InSe is resistance to ionizing radiation [4], which extends their practical application. The doping of InSe crystals with cadmium changes $n$-type conductivity to $p$-type, which allows change the band offset of the heterojunctions.

A weak van der Waals coupling between layers and a strong ionic-covalent inside layer in InSe defines the peculiarities of the physical properties of the crystals. In particular, existing structural defects substantially affect electrical properties. Packaging defects, dislocation nets placed in the (0001) plane generate additional energy barriers $E_{\delta}$ for the motion of charge carriers along the $\boldsymbol{C}$ axis, which results in significant anisotropy of the electrical conductivity. There are localized states near the Fermi level $[5,6]$ due to the presence of vacancies and dislocations. A high density of states in the band gap defines the electronic process in InSe, including hopping conduction mechanism that has already been studied in InSe $<\mathrm{Mn}>$ crystals in direct current electric field [7].

In this work we report the results of investigations of the direct current (DC) and alternating current (AC) electrical conductivity of $p$-InSe single along and across the $\boldsymbol{C}$ axis.

\section{Experimental}

InSe $<\mathrm{Cd}>$ single crystals were grown by the Bridgman method from a nonstoichiometric melts
$\mathrm{In}_{1.03} \mathrm{Se}_{0.97}<0.1$ mass $\% \mathrm{Cd}>$ in quartz ampoules. The technology used the initial components of In-000, highpurity Se 22-6, Cd-0000. Doping with cadmium provided the $p$-type conductivity of the material. The determination of the crystal structure of the grown single crystals was performed by using a DRON-3 installation in $\mathrm{CuK}_{\alpha}$-radiation.

Rectangular samples for the measurements of the electrical properties had ohmic contacts, which were prepared using high-purity In. DC electrical conductivity were measured in the temperature range 80 to $275 \mathrm{~K}$ along $\left(\sigma_{\perp C}\right)$ the layers. The samples for conductivity measurements had the conventional geometry of six contacts.

Frequency dependences of the electrical conductivity were investigated by using a "Solartron 1255 FRA" frequency response analyzer (frequency range is 0.1 $10^{6} \mathrm{~Hz}$, amplitude of a sinusoidal signal is $5 \mathrm{mV}$ ). Studies were carried out at room temperature.

\section{Results and discussion}

Grown $\operatorname{InSe}<0.1$ mass \% Cd $>$ crystals had $p$-type conductivity, the free carriers concentration $p \approx$ $10^{14} \mathrm{~cm}^{-3}$, and the Hall mobility $\mu \approx 50 \mathrm{~cm}^{2} /(\mathrm{V} \cdot \mathrm{s})$ at room temperature. The calculated concentration of impurity atoms was $3 \cdot 10^{19} \mathrm{~cm}^{-3}$.

From the carried out X-ray studies it was found that $\mathrm{InSe}<\mathrm{Cd}>$ has a monocrystalline structure. Fig. 1 shows the diffraction pattern of $p$-InSe $\langle\mathrm{Cd}\rangle$ single crystal taken from the (0001) surface. There are no additional peaks corresponding to the microinclusion of another phase on the diffraction pattern. The measured parameters of the elementary cell $a=4.004, c=$ 


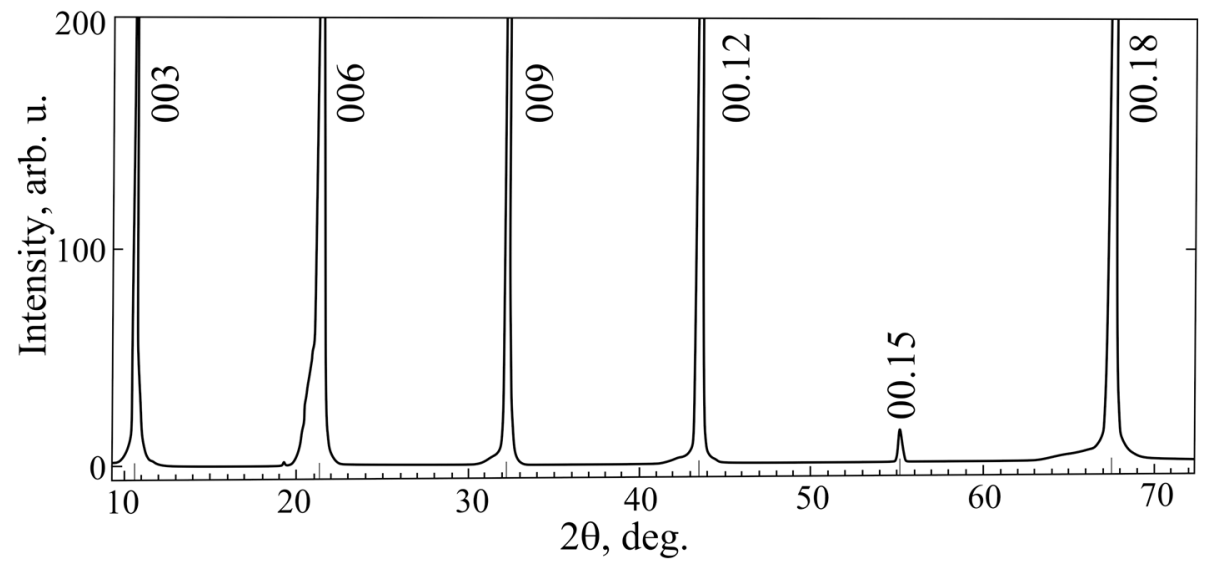

Fig. 1. X-ray diffraction pattern of $\mathrm{InSe}<\mathrm{Cd}>$ crystal.
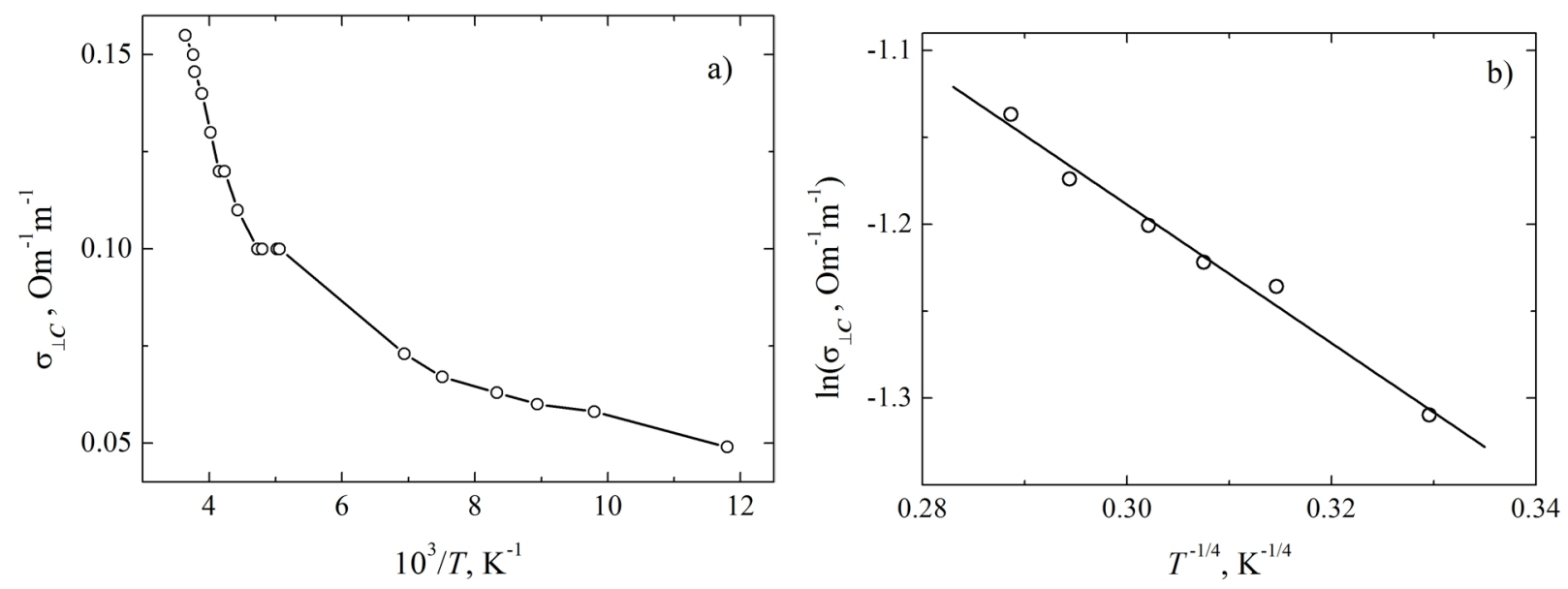

Fig. 2. Temperature dependence of the electrical conductivity of $\operatorname{InSe}<\mathrm{Cd}>$ crystal.

$24.960 \AA$ exceed slightly the sizes of InSe cell $(a=$ $4.003 \pm 0.001, c=24.9553 \pm 0.0006 \AA)$ due to the deformation of the $\mathrm{InSe}<\mathrm{Cd}>$ crystal lattice.

The hopping conductivity mechanism along $\boldsymbol{C}$ axis $\left(\sigma_{\| C}\right)$ previously studied in InSe and $\mathrm{InSe}<\mathrm{Mn}>$ crystals at $\mathrm{T}<160 \mathrm{~K}[7,8]$ as well as in $\mathrm{InSe}<\mathrm{Cd}>$ thin films [9]. In this work the temperature dependence of the electrical conductivity across the crystallographic $\boldsymbol{C}$ axis $\left(\sigma_{\perp C}\right)$ of InSe $<\mathrm{Cd}>$ crystal are shown (Fig. 2a). The dependence of $\sigma_{\perp C}(T)$ has a semiconductor character. Is it possible to suppose that the growth of the electrical conductivity in the low temperature range $(80-160 \mathrm{~K})$ is due to the hopping conductivity mechanism like $\mathrm{InSe}<\mathrm{Sn}>$ crystals [6], and there is an activation of acceptor levels in the high temperature range (> $200 \mathrm{~K}$ ).

The temperature dependence of the conductivity $\sigma_{\perp C}$ of InSe $\langle\mathrm{Cd}\rangle$ crystals at $\mathrm{T}<160 \mathrm{~K}$ in the Mott coordinates $\ln \left(\sigma_{\perp C}\right)-T^{-1 / 4}$ (Fig. 2b) has a linear character, which confirms the hopping conductivity mechanism. The parameters calculated according to the theory of hopping conductivity [10]: density of states near the Fermi level $N\left(E_{F}\right)=2.8 \cdot 10^{20} \mathrm{~cm}^{-3} \mathrm{eV}^{-1}$, average hopping length $R(115 \mathrm{~K})=140 \AA$, bandwidth of the levels near $E_{F} W(115 \mathrm{~K})=13 \mathrm{meV}$. The following parameters were used in calculation: localization radius $\mathrm{a}_{0} \approx 50 \AA$, $\beta=21[8]$.

For the model of compensated $\mathrm{InSe}<\mathrm{Cd}>$ semiconductor [9] the temperature dependence of the hole concentration $p \sim T^{3 / 2} \cdot \exp \left(-E_{d} / k T\right)$. It is known that in InSe mobility at high temperatures is defined by optical phonon scattering $\left(\mu \sim T^{-3 / 2}\right)$. Using the relation $\sigma=e p \mu$ we find $\sigma \sim \exp \left(-E_{a} / k T\right)$. This allows us to estimate the activation energy of the acceptor levels according to the dependence of $\ln \sigma_{\perp C}$ from $1 / T$ (Fig. 3): $E_{a}=36.2 \mathrm{meB}$. The obtained value of $E_{a}$ is agreed with the activation energy of carriers $(28-41 \mathrm{meV})$ in InSe $<\mathrm{Cd}>$ films [9].

The electrical parameters of InSe (electrical conductivity, mobility, concentration of free carriers) are defined by the structural perfection of grown crystals. Xray structural studies of initial InSe shows that crystals can be blockless, block and mosaic depending on the conditions of the grown. Measured with a two-crystal Xray spectrometer in $\mathrm{CuK}_{\alpha 1}$ radiation, the half-width of the reflection 004 was 72", the dispersion of the device did not exceed $2 \cdot 10^{-2} \AA^{-1}$. In mosaic crystals, the disorientation of the single microblocks are in the order of 10 angular seconds, their size is $l \approx 1.6 \cdot 10^{-2} \mathrm{~cm}$. The calculation of the band parameters of the hopping conductivity was performed for model of blockless single crystal. For mosaic crystals, calculations should be made according to the formula $\sigma T^{1 / 2}=\sigma_{0} \exp \left(-T_{0} / T\right)^{1 / 4}$, as in the case of thin films [10] and polycrystals. 


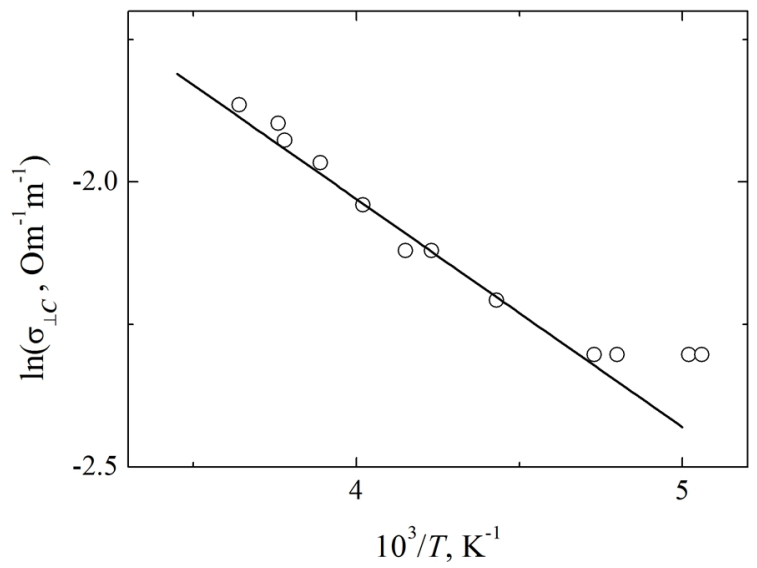

Fig. 3. Temperature dependence of the electrical conductivity of $\mathrm{InSe}<\mathrm{Cd}>$ crystal.

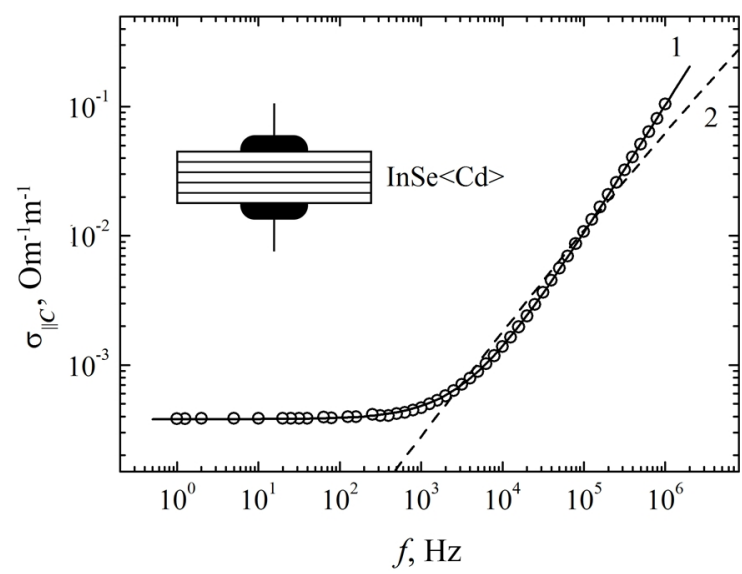

Fig. 4. Frequency dependences of the effective values of the electrical conductivity of $\mathrm{InSe}<\mathrm{Cd}>$ crystal.

The hopping conductivity mechanism of $\operatorname{InSe}<\mathrm{Cd}>$ was investigated in an AC field along the crystallographic $\boldsymbol{C}$ axis. Fig. 4 shows the frequency dependences of the effective values of the conductivity at room temperature. The obtained dependence corresponds to the power law $\sigma(f)=\sigma_{0}+A \cdot f^{n}\left(\sigma_{0}\right.$ is the DC electric conductivity, $0<n<1$ ) [11]. The second term is the polarization component of the electric conductivity, which corresponds to the hops of carriers between localized states near the Fermi level. fig. 4 (curve 1) shows the results of the fit by least squares method with the following parameters: $\sigma_{0}=3.8 \cdot 10^{-4} \mathrm{Om}^{-1} \mathrm{~m}^{-1}, A=$ $1.02 \cdot 10^{-7}, n \approx 1$ (mean square error $2.6 \%$ ).

The parameters calculated according to the theory of hopping AC electric conductivity [12]: density of states near the Fermi level $N\left(E_{F}\right)=4 \cdot 10^{20} \mathrm{~cm}^{-3} \mathrm{eV}^{-1}$, average hopping length $R\left(10^{5} \mathrm{~Hz}\right)=123 \AA$, bandwidth of the levels $\Delta E\left(10^{5} \mathrm{~Hz}\right)=0.64 \mathrm{meV}$, average hopping time $\tau$ $\left(10^{5} \mathrm{~Hz}\right)=10 \mu \mathrm{s}$. The following parameters were used for calculation: localization radius $14 \AA$ [5], phonon frequency $v_{\mathrm{ph}}=4 \cdot 10^{12} \mathrm{~Hz}$. Fig. 4 (curve 2) shows the theoretical frequency dependence of $\sigma_{\| C}(f)$, which corresponds to the given parameters.

\section{Conclusion}

The measurements in a direct and an alternating electric fields indicates hopping mechanism of electrical conductivity along and across to the layers in $\mathrm{InSe}<\mathrm{Cd}\rangle$ crystals. It is shown that $\sigma_{\perp C}$ in a constant electric field at low temperatures $(<160 \mathrm{~K})$ and $\sigma_{\| C}$ in an alternating electric field at room temperatures are defined by the hops of carriers between localized impurity states. At high temperatures $(>160 \mathrm{~K}), \sigma_{\perp C}$ shows an activated character.

Kaminskii V.M. - candidate of physico-mathematical sciences, researcher;

Kovalyuk Z.D. - professor, doctor of physicomathematical sciences, chief;

Ivanov V.I. - candidate of physico-mathematical sciences; researcher;

Tkachuk I.G. - PhD student;

Netyaga $\boldsymbol{V} . \boldsymbol{V}$. - candidate of physico-mathematical sciences, senior researcher.

[1] I.G. Orletsky, M.I. Ilashchuk, V.V. Brus, P.D. Marianchuk, M.M. Solovan, Z.D. Kovalyuk, Semiconductors 50(3), 334 (2016).

[2] W. Feng, W. Zheng, W. Cao, P.A. Hu, Adv. Mater. 26(38), 6587 (2014).

[3] R.T. Srinivasa, Y.-Y. Lu, U. Rajesh Kumar, R. Sankar, C.-D. Liao, B. Karukanara Moorthy, C.-H. Cheng, F.C. Chou, Y.-T. Chen, Nano Lett. 14(5), 2800 (2014).

[4] Z.D. Kovalyuk, O.A. Politanska, O.N. Sydor, V.T. Maslyuk, Semiconductors. 42(11), 1292 (2008).

[5] S.N. Mustafaeva, Physics of the Solid State. 46(6), 1008 (2004).

[6] S.N. Mustafaeva, A.A. Ismailov, M.M. Asadov, Low temperature physics. 36(4), 310 (2010).

[7] V.M. Kaminskii, Z.D. Kovalyuk, A.V. Zaslonkin, V.I. Ivanov, Inorganic materials, 48(2), 1 (2012) (in Russian).

[8] G.L. Belen'kii, N.A. Abdullaev, V.N. Zverev, V.Ya. Shteinshraiber, JETP Letters. 47(10), 584 (1988).

[9] A.F. Qasrawi, I. Günal, C. Ercelebi, Cryst. Res. Technol. 35(9), 1077 (2000).

[10] B.I Shklovskii, A.L. Efros, Electronic properties of doped semiconductors (Springer-Verlang, Berlin, 1984).

[11] A.K. Jonscher, J. Phys. C: Solid State Phys. 6, L235 (1973).

[12] N.F. Mott, E.A. Davis, Electron processes in non-crystalline materials (Claredon Press, Oxford, 1979). 
V.M. Kaminskii, Z.D. Kovalyuk, V.I. Ivanov, I.G. Tkachyuk, V.V. Netyaga

В.М. Камінський, З.Д. Ковалюк, В.І. Іванов, І.Г. Ткачук, В.В. Нетяга

\section{Електричні властивості кристалів $\operatorname{InSe}<\mathrm{Cd}>$}

Інститут проблем матеріалознавства ім. І.М. Францевича Національної академії наук України, Чернівецьке відділення, вул. I. Вільде 5, м. Чернівиі, 58001, Україна, e-mail chimsp@ukrpost.ua

Проведено виміри електропровідності вздовж (в змінному електричному полі) і перпендикулярно (в постійному електричному полі) кристалографічної осі $\boldsymbol{C}$ кристалів селеніду індію легованого кадмієм. Розраховані параметри стрибкової провідності в $\mathrm{InSe}<\mathrm{Cd}>$.

Ключові слова: шаруватий кристал, селенід індію, електропровідність. 